\title{
Graduate Student End-of-Term Satisfaction with Group-Based Learning in EFL Classroom
}

\author{
Wen $\mathrm{Li}^{1} \&$ Shoukuan $\mathrm{Mu}^{2}$ \\ ${ }^{1}$ School of Foreign Languages, Minnan Normal University, Zhangzhou, China \\ ${ }^{2}$ School of Educational Sciences, Minnan Normal University, Zhangzhou, China \\ Correspondence: Shoukuan Mu, School of Educational Sciences, Minnan Normal University, Zhangzhou, \\ 363000, Fujian, China. E-mail: msk1967@163.com
}

$\begin{array}{ll}\text { Received: April 3, } 2014 & \text { Accepted: June 23, } 2014 \quad \text { Online Published: July 15, } 2014 \\ \text { doi:10.5539/elt.v7n8p62 } & \text { URL: http://dx.doi.org/10.5539/elt.v7n8p62 }\end{array}$

\begin{abstract}
The current study explored graduate student end-of-term satisfaction with group learning, compared with traditional instructor-led instruction in EFL (English as a foreign language) classroom. Participants were 74 graduate students, including 33 males and 41 females from a normal university in southern China. The study was carried out with two classes by different teaching methodologies respectively, one was group-based (n/35) with nine groups, and the other was instructor-led class (n/39). Students were assigned randomly to the two types of classes ahead of the formal lessons and taught by the same instructor during the period of an academic term. At the end of the term, a questionnaire survey was administered to all the students of the two classes to measure their satisfaction with English class learning. The results showed students with group-based instruction were more satisfied than those who took the course under the instructor-led format. Also, no significant differences existed between groups with respect to satisfaction. The results of the analysis were discussed and directions for further study were suggested. The significance of the present study lies in the fact that it was able to explore the difference in student satisfaction between group-learning and instructor-led settings in EFL class, and both instructor(s) and students should shift their focus "from what is being taught to what is being learned" in EFL classroom.
\end{abstract}

Keywords: EFL classroom, group-based learning, instructor-led instruction, satisfaction

\section{Introduction}

\subsection{Context of the Study}

Since China opened its doors to the world in the early 1980s, English has been the dominant foreign language and is required to take as a compulsory course in primary schools, secondary schools and higher education institutions. Millions of EFL learners take regular English courses, 4 class hours a week, 18 weeks a term, for 12 terms in high school and 4-8 terms at university (Chen \& Goh, 2010; Rao, 2013; Wu, 2001). In a traditional EFL (English as a foreign language) classroom, during the whole class time, the instructor explains new English words and grammar directly and orally to all students, or translates English texts into Chinese sentence by sentence; students listen and take notes for most of the time; once in a while, students are asked to answer some questions or to translate English sentences into Chinese, or vice versa. After learning the text, students are asked to finish some exercises to consolidate newly-learned knowledge; for listening practice, the instructor plays the audiotapes or videotapes for students to listen or watch, and then to do some exercises to develop their listening skills; sometimes, students are asked to practice dialogues in pairs to develop speaking skills. In short, English teaching in China is dominated by a teacher-centered, book-centered, grammar-translation method and an emphasis on rote memory (Rao, 1996).

In practice, unfortunately, these efforts are not always fruitful. The concept of English study was nothing "more than memorizing grammar rules and facts in order to understand and manipulate the morphology and syntax of the foreign language" (Richard \& Rodgers, 2001). According to a research report (S. Wang \& H. Wang, 2011), approximately $83 \%$ of college and university students in China feel dissatisfied with their English learning, they think after learning English for quite a few years, they might have learned quite a lot of English words and grammatical points and how to translate English texts, but they can neither understand what the English speakers 
say nor can they express themselves freely; So in spite of the years of formal language instruction, Chinese university students' English proficiency particularly in listening and speaking is far from satisfactory (Chen \& Goh, 2010; Liu \& Dai, 2003; Wen, 1999).

This kind of situation is reflected in one of the co-authors' teaching practice, too. As a responsible teacher, I (the co-author) have been teaching students English in the traditional EFL method for many years; often, I find my students do not concentrate in class. Once I made an investigation, interviewing them individually why they greeted negatively. There were many different answers, but two points on which they all agreed: they are only listeners, note takers and knowledge receivers; they do not learn much from English class. The investigation produced me thinking about changing teaching method in class until I read the research literature on small groups.

Related reviews of group learning activities suggest that group learning appears to be a valuable way to actively involve students work together and to build an effective learning environment. For example, Mutch (1998) pointed out that group discussion encourages students to explore different perspectives about content. A meta-analysis study (Lou et al., 1996) suggested that within-class grouping appears to be a useful means to facilitate student learning. Similarly, according to Towns, Kreke, and Fields (2000), exploring information together encourages students to take greater ownership of their learning and sharing knowledge helps students learn from each other and develops a community of learning. Furthermore, some researchers found that group learning may lead to positive outcomes such as higher achievement, increased performance, better critical thinking, more positive attitudes towards learning, increased persistence and retention (Gokhale, 1995; Mullen \& Copper, 1994; Slavin, 1987; Springer, Stanne, \& Donovan, 1999; Webb, 1989).

Group learning appealed so much to me that I decided to introduce it into class in 2011 academic term, aiming to have a comparison with traditional instructor-led method. It should be pointed out that in studies mentioned above, small groups were used for only a portion of class time, for only a fraction of a term, or for some activities, no empirical studies, however, appeared considering whether the use of group learning activities is related to any long-term course outcomes. For this study, we focused on student end-of-term (one fall term) satisfaction with group-based learning in EFL class. We choose satisfaction as outcome measure, because although satisfaction may not be the ultimate goal for all instructors in all courses, considerable research indicates that global measures of satisfaction are significantly related to objective assessments of student learning and teaching behaviors (Foster \& Hermann, 2011).

\subsection{Purpose of the Study}

The study was conducted to explore student end-of-term satisfaction with group learning, compared with traditional instructor-led class. Therefore, it intended to make comparison between group-based and instructor-led instruction in EFL Class. By contrast, in a group-based class, students learn in groups, teaching was more student-centered than instructor-centered, in effect, the instructor was no longer the dominating authority in class, but the facilitator to the learning process in the classroom, class performance was not just managed by the teacher but by all the teacher and students. Specifically, our study aimed to answer the following two questions: (1) Were students with group learning instruction more satisfied than those who took the course under the traditional instructor-led format in EFL class? (2) Were there any significant differences in student satisfaction among the learning groups?

\section{Method}

\subsection{Participants}

Participants in this study were 74 first-year graduate students in all $(\mathrm{n} / 74)$, including 33 males and 41 females (ages between 21 and 37, mean $=25.08, \mathrm{SD}=2.58$ ). They were enrolled English as a compulsory course for graduation from a normal university in southern China. All the students had learned English for 10 years or so. They had to pass official English Test for Graduate Candidate (GCET), (a compulsory subject in the national postgraduate entrance examination, administered by Testing Center of the Chinese Ministry of Education). The study was carried out with two classes, one was group-based (n/35) with nine groups, each made up of 3-6 students, the other was instructor-led class (n/39). Students were assigned randomly to the two types of classes ahead of the formal lessons, they were generally of a similar proficiency level, with a score of 55-70 on the GCET test.

\subsection{Procedure}

During the whole term, both of the two classes were taught by the same instructor (the first author), with the same set of subject materials employed for all the students (n/74) except different teaching instructions. While 
exploring the difference in student satisfaction between group-based and instructor-led class settings, we controlled for a number of factors that could potentially create differences between the two classes. Students were asked to self-report their GCET score, year of learning English in school and college.

In the first lesson of group-based class, the whole class was divided into nine groups freely, with each made up of three to six students, the purpose of doing so was to save time in establishing harmonious relationships of cooperation among group members to obtain a higher degree of integration of the whole group. Later, students studied new materials together in small groups. Usually at the very beginning of each lesson, the instructor presented clear teaching content and requirements, which included the meaning and grammar of the EFL texts, text-after exercises, listening and speaking skills practice. Learning tasks might vary in the process of learning new unit. During the time that followed, students learned according to the way they liked in their group, such as discussing procedural issues and content, explaining materials to others, asking each other questions, debating and discovering solutions, or making up stories related to the theme of the text. The instructor walked around to provide groups necessary guide and support when they asked for help. That is, the instructor helped to guide the students, manage their activities, and direct their learning, she was the helper of students learning.

Whereas instructor-led class was conducted in a traditional EFL teaching way. As previously noted, the instructor read and explained new passages orally to all students to help them understand some difficult points, or sentence structures, students just listened and took notes silently and understood content further, or they sat and practiced the skills (sometimes in pairs or groups for a short while) taught by the instructor, and did the tasks required by the instructor. The instructor was the center of classroom activities. The role of the instructor was the transmitter of knowledge.

At the end of the term, a total of 74 students were asked to complete the questionnaire survey in their last class respectively. In order to guarantee the validity of filling in the questionnaire, all the students were told clearly that their participation would not affect their term grades, but it was a part of their course so that they could do it carefully. At the time the questionnaire was administered, the instructor left the classroom and didn't return until the survey was completed.

\subsection{Instrument}

For the purpose of this study, a questionnaire survey was constructed including questions focusing on students' perceived learning experiences to measure the learning satisfaction of students. In the context of education, student satisfaction refers to the favorability of a student's subjective evaluations of the various outcomes and experiences associated with education (Oliver \& DeSarbo, 1989). Student satisfaction is constantly being influenced by the students' overall experiences (Oliver, 1980). Student satisfaction with the course and the instructor were measured (I feel the course was very rewarding; I am satisfied with the efforts of the instructor), as it is a widely used parameter that may indicate the effectiveness of learning environments (Piccoli, Ahmad, \& Ives, 2001); the survey assessed students' perceptions of how it might help learning (I learned a lot and could use some of the skills from my regular lesson); the survey was also constructed from the psychological argument that process of communication is, in an important sense, a learning process (Allwright, 1984) (I was helpful and collaborated well with others; I enjoyed learning with classmates). Students rated the degree to which they agreed with the statements on a 5-point Likert scale from 1 representing strongly disagree to 5 representing strongly agree. The reliability (Cronbach's alpha) in the current study was 0.72 .

\subsection{Data Analysis}

Descriptive statistical method was used to describe the satisfaction based on instructor-led learning, group-based learning and different groups. Non-parametric tests were used for analyzing the differences of satisfaction based on groups, as distributional data could not be obtained owing to the low number of observations. To begin with, the satisfaction scores between the groups were analyzed for independent sampling using the Kruskal-Wallis $H$ test. T-test was used to calculate the differences in student satisfaction based upon the different teaching methodology.

\section{Results}

Table 1 shows descriptive statistics of satisfaction based on instructor-led learning, group-based learning and groups, including mean, standard deviation, mean rank and sample sizes. The Kruskal-Wallis $H$ test showed that there were no significant differences in student satisfaction among the learning groups, $H(8)=9.48, p=.30$. T-test results showed there was a significant difference in student satisfaction based on the teaching methodology. Students with small-group instruction reported higher satisfaction than students with instructor-led instruction, $t(72)=4.96, p<.001$. 
Table 1. Descriptive statistics of satisfaction based on instructor-led learning, group-based learning

\begin{tabular}{lllll}
\hline & $\mathrm{M}$ & $\mathrm{SD}$ & Mean Rank & $\mathrm{N}$ \\
\hline Instructor-led learning class & 16.23 & 3.53 & & 39 \\
Group-based learning class & 19.57 & 1.94 & & 35 \\
Group 1 & 18.33 & 2.31 & 12.33 & 3 \\
Group 2 & 19.70 & 1.37 & 19.00 & 6 \\
Group 3 & 19.00 & 1.83 & 15.38 & 4 \\
Group 4 & 18.00 & 2.16 & 10.62 & 4 \\
Group 5 & 21.33 & 1.53 & 27.33 & 3 \\
Group 6 & 20.25 & 1.26 & 21.62 & 4 \\
Group 7 & 18.75 & 2.06 & 14.12 & 4 \\
Group 8 & 19.33 & .58 & 15.83 & 3 \\
Group 9 & 21.50 & 2.38 & 25.62 & 4 \\
\hline
\end{tabular}

\section{Discussion and Conclusions}

This study examines the degree to which student satisfaction is influenced by course type (group-based vs. instructor-led). The course was taught by the same instructor and set of subject material and questionnaire survey were held during the same term and between the two types of course. Higher satisfaction was found in favor of group-based learning instruction, when compared with traditional instructor-led lecture format. This was partly in agreement with the findings of a previous study (Lou et al., 1996). Their meta-analysis research suggested that there were small but positive effects of placing students in groups within the class for learning, while results in the present study showed that significant difference on satisfaction appeared when two instruction formats were compared. This fact supports the idea that group-based teaching method was successful in promoting effective student learning and making them more satisfied with English classroom learning. Students learned together in groups, they taught by themselves and learned from each other, just as Biggs (1999) suggested that peer-directed teaching and learning activities offer positive outcomes for students such as the elaboration of known content, the opportunity to develop skills for judging better and worse peer interpretations, and an increasing awareness of the cognitive processes students undergo in arriving at a particular position.

Effort was made while designing the group-based learning. At the very beginning of the first class, students formed groups freely by themselves to achieve a high degree of interaction which might lead to good communication in subsequent process of learning. In the process of group learning, students learned according to the way they like, there were diversity of group activities, like discussing, explaining, debating, and making up stories, which led to much more communication between and among students. Thus, the communication of ideas that matter to the learner is likely to aid learning by getting learners more deeply involved in what they are doing (Moskowitz, 1978), and it is through interaction between speaker and listener meaning becomes clear (Larsen-Freeman, 1986). Furthermore, interactions with peers are often more entertaining than listening to lectures; the students develop communication skills and self-knowledge and have the opportunity to initiate friendships amongst their peer group (Finlay \& Faulkner, 2005).

It is worth emphasizing that the group-based class was designed with the exact same content as the instructor-led class, meaning the teaching method was adapted to the learning content, and not vice versa. Furthermore, it supports the argument that quality method leads to higher student satisfaction of class learning, regardless of the medium through which a course is being taught, that is, to some degree, the quality of the learning experience is determined by the method used in class, not the instructor. The most important finding of this study was introducing group learning into EFL classroom requires that both instructor(s) and students shift their focus "from what is being taught to what is being learned".

The findings gave us a better understanding of group-learning instruction which might produce positive outcome as higher satisfaction, compared with traditional instructor-led instruction. Group-learning instruction could be generalized to adults of all ages for EFL learning. It should be noted that in our study the group-based class was divided into nine groups, which were formed by the students themselves, the results indicated no significant differences existed among groups with respect to satisfaction (see Table 1). Given the low number of groups, 
differences may occur in the population more broadly, though this is not the focus of our current study, finding which type of grouping is best in the stage of language learning in EFL class is very important, which should be explored further.

It should be pointed out that there are limitations to the study described. The two samples were relatively small due to the small-sized classes. Future study could be extended to a broader group of the period of college and university study, with more variables such as motivation, learning strategies and learning styles into consideration to examine how student satisfaction would be affected. Additionally, the study covered only one term of an academic year, the duration of the study could be one year or even more to the whole phase of graduate study. In sum, our study was just a preliminary exploration but of important practical value, which could provide EFL educators and educational institutions a solution to teach EFL, also, with some very valuable insights into student behavior and associated outcomes in EFL class.

\section{Acknowledgements}

The authors would like to express their sincere thanks to the journal editor and the reviewers for their thoughtful comments on this paper.

\section{References}

Allwright, R. (1984). The importance of interaction in classroom language learning. Applied Linguistics, 5(2), 156-171. http://dx.doi.org/10.1093/applin/5.2.156

Biggs, J. (1999). Teaching for quality learning at university. Buckingham: Open University Press.

Chen, Z., \& Goh, C. (2010). Teaching oral English in higher education: Challenges to EFL teachers. Teaching in Higher Education, 16(3), 333-345. http://dx.doi.org/ 10.1080/13562517.2010.546527

Finlay, S. J., \& Faulkner, G. (2005). Tête à tête: Reading groups and peer learning. Active Learning in Higher Education, 6(1), 32-45. http://dx.doi.org/10.1177/1469787405049945

Foster, D. A., \& Hermann, A. D. (2011). Linking the first week of class to end-of term satisfaction: Using a reciprocal interview activity to create an active and comfortable classroom. College Teaching, 59(3), 111-116. http://dx.doi.org/10.1080/87567555.2011.572098

Gokhale, A. A. (1995). Collaborative learning enhances critical thinking. Journal of Technology Education, 7(1), $22-30$.

Liu, R., \& Dai, M. (2003). Foreign language teaching reform in higher education in China: A study of current status and developmental strategies. Beijing: Foreign Language Teaching and Research Press.

Larsen-Freeman, D. (1986). Techniques and principles in language teaching. Oxford: Oxford University Press.

Lou, Y., Abrami, P. C., Spence, J. C., Poulsen, C., Chambers, B., \& D’Apollonia, S. (1996). Within-class grouping: A meta-analysis. Review of Educational Research, 66(4), 423-458.

Moskowitz, G. (1978). Caring and sharing in the foreign language class. Rowley, MA: Newbury.

Mullen, B., \& Copper, C. (1994). The relation between group cohesiveness and performance: An integration. Psychological Bulletin, 115(2), 210-227. http://dx.doi.org/10.1037//0033-2909.115.2.210

Mutch, A. (1998). Employability or learning? Group work in higher education. Education \& Training, 40(2), 50-56.

Oliver, R. L. (1980). A cognitive model of the antecedents and consequences of satisfaction decisions. Journal of Marketing Research, 17(4), 460-469.

Oliver, R. L., \& DeSarbo, W. S. (1989). Processing of the satisfaction response in consumption: A suggested framework and research propositions. Journal of Consumer Satisfaction, Dissatisfaction, and Complaining Behavior, 2, 1-16.

Piccoli, G., Ahmad, R., \& Ives, B. (2001). Web-based virtual learning environments: A research framework and a preliminary assessment of effectiveness in basic IT skills training. MIS Quarterly, 25(4), 401-426. http://dx.doi.org/10.2307/3250989

Rao, Z. H. (1996). Reconciling communicative approaches to the teaching of English with traditional Chinese methods. Research in the Teaching of English, 30(4), 458-471.

Rao, Z. H. (2013). Teaching English as a foreign language in China: looking back and forward. English Today, 29, 34-39. 
Richards, J. C., \& Rodgers, T. S. (2001). Approaches and methods in language teaching (2nd ed.). Cambridge: Cambridge University Press. http://dx.doi.org/10.1017/CBO9780511667305

Slavin, R. E. (1987). Ability grouping and student achievement in elementary schools: A best evidence synthesis. Review of Educational Research, 57(3), 293-336.

Springer, L., Stanne, M. E., \& Donovan, S. S. (1999). Effects of small-group learning on undergraduates in science, mathematics, engineering, and technology: A meta-analysis. Review of Educational Research, 69(1), 21-51. http://dx.doi.org/10.3102/00346543069001021

Towns, M. H., Kreke, K., \& Fields, A. (2000). An action research project: Student perspectives on small-group learning in chemistry. Journal of Chemical Education, 77(1), 111-116.

Wang, S. R., \& Wang, H. X. (2011). Investigation on the current situation in college English teaching and reform and the development direction. FLC, 8(5), 4-17.

Webb, N. M. (1989). Peer interaction and learning in small groups. International Journal of Educational Research, 13, 21-39.

Wen, Q. F. (1999). Testing and teaching spoken English. Shanghai: Shanghai Foreign Language Education Press.

Wu, Y. A. (2001). English language teaching in China: Trends and challenges. TESOL Quarterly, 35(1), 191-194.

\section{Copyrights}

Copyright for this article is retained by the author(s), with first publication rights granted to the journal.

This is an open-access article distributed under the terms and conditions of the Creative Commons Attribution license (http://creativecommons.org/licenses/by/3.0/). 